Franchuk V.P., D.Sc. (Tech.), Professor, Bondarenko A.A., D.Sc. (Tech.), Professor, Titov A.A., Ph.D. (Tech.), Associate Professor (SHEI «NMU»)

\title{
SUBSTANTIATION OF METHOD FOR CALCULATING DESIGN PARAMETERS OF HORIZONTAL HYDRAULIC CLASSIFIER
}

Франчук В.П., д-р техн. наук, профессор, Бондаренко А.А., д-р техн. наук, профессор,

Титов А.А., канд. техн. наук, доцент $($ ГВУЗ «НГУ»)

\section{ОБОСНОВАНИЕ МЕТОДА РАСЧЕТА КОНСТРУКТИВНЫХ ПАРАМЕТРОВ ГОРИЗОНТАЛЬНОГО ГИДРАВЛИЧЕСКОГО КЛАССИФИКАТОРА}

\author{
Франчук В.П., д-р техн. наук, професор, \\ Бондаренко А.O., д-р техн. наук, професор, \\ Титов О.О., канд. техн. наук, доцент \\ (ДВНЗ «НГУ») \section{ПАРАМЕТРІВ ГОРИЗОНТАЛЬНОГО ГІДРАВЛІЧНОГО КЛАСИФІКАТОРА} \\ ОБГРУНТУВАННЯ МЕТОДУ РОЗРАХУНКУ КОНСТРУКТИВНИХ
}

\begin{abstract}
Process of gravitational treatment of granular materials in the pulp horizontal flow is accompanied by bearing stream flowing within differently inclined surfaces and by downstream of condensed pulp. In the article, method for calculating design parameters of horizontal classifier is validated, which is based on construction of trajectories of solid particle motion.

For this purpose, process of liquid elementary particle moving in the flow is considered. Trajectory of the liquid elementary particle or solid particle motion is constructed by determining the particle current coordinate in accordance with the Lagrange method. Trajectory of solid particle motion in characteristic sections of horizontal classifier is constructed with the help of expressions for calculating values of sedimentation depth increment.
\end{abstract}

Key words: gravitational separation, horizontal classifier, motion trajectory.

\section{INTRODUCTION}

Separation of clay and oozy particles from feeding is traditionally fulfilled in gravitational apparatuses with horizontal motion of carrying flow: horizontal classifiers, spiral classifiers, desludgers, horizontal settlers etc. The prefferable equipment allowing efficient separation of fine impurities of size less than $0,16 \mathrm{~mm}$ is horizontal hydraulic classifier. The scheme of flowing area of classifier is given in fig. 1. The process of gravitational treatment of granular materials in horizontal pulp flow features carrying flow being limited by surfaces of different inclination values, 
also condensed pulp flowing downwards within areas of separation, sedimentation and flow. Substantiation of design parameters of horizontal classifier requires development of a method, based on mathematical model of flow motion in classifier flowing area, taking into consideration known models of flow speed distribution on its depth.

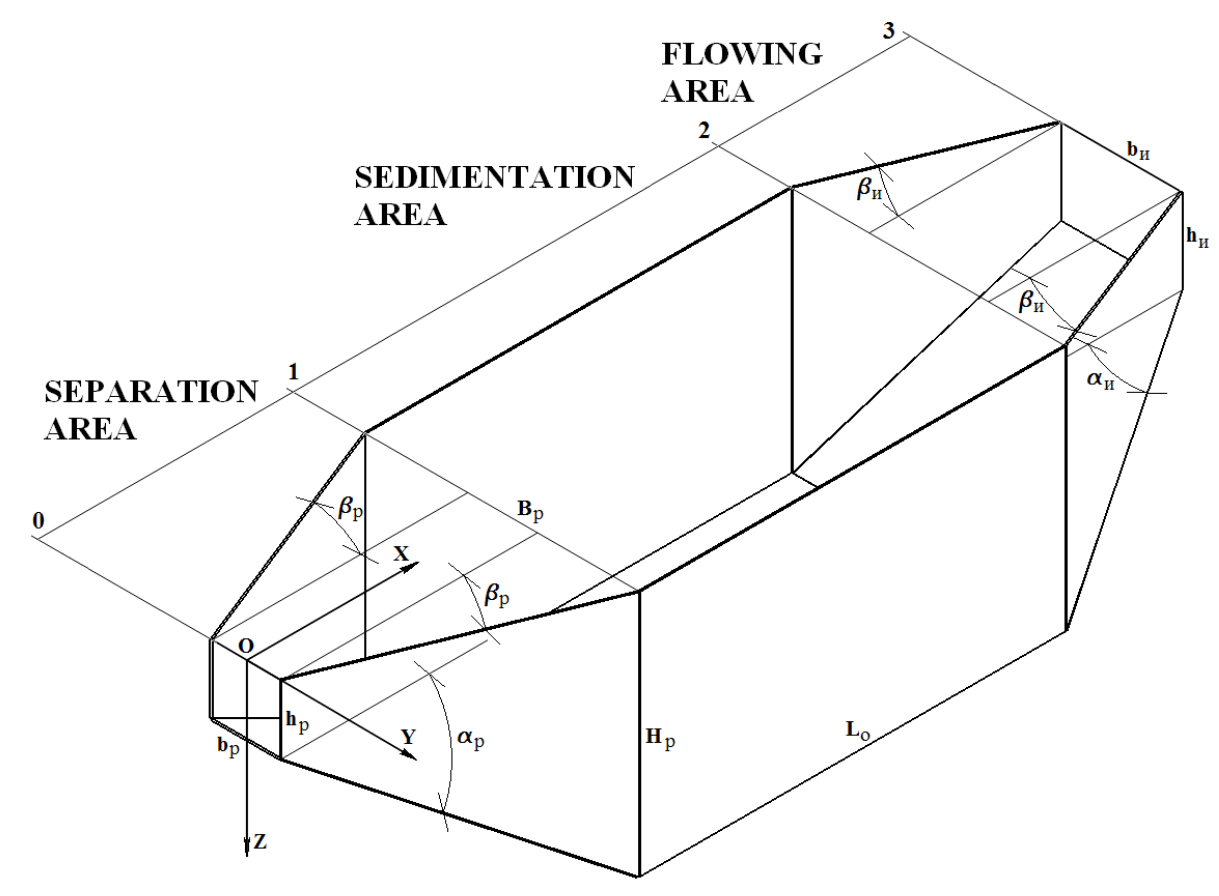

Figure 1 - Scheme of flowing area of horizontal hydraulic classifier

\section{Rewiew of publications}

It is known, that usage of hydraulic classifiers with horizontal flow is rational during separation of granular material of size less than $2 \mathrm{~mm}$ [1-6]. Description of liquid flow motion in a horizontal classifier is fulfilled using Euler equation for ideal (non-viscous) liquid [7], [Bogomolov A.I., 1972]. Authors obtained mathematical model of liquid flow in flowing area of horizontal hydraulic classifier and also values of flow speed $u_{x}, u_{y}, u_{z}$ and acceleration $\frac{d u_{x}}{d t}, \frac{d u_{y}}{d t}, \frac{d u_{z}}{d t}$ within typical segments of the process. Obtained model is intended to describe the process of solid particles sedimentation, accelerated by pulp carrying flow, also to obtaine rational parameters of devices used for gravitational processing of granular materials.

The following designations are introduced in order to describe the process of carrying media motion: $Q_{p}, Q_{o}, Q_{u^{-}}$productivities on pulp within areas of separation, sedimentation and flow, $\mathrm{m}^{3} / \mathrm{hr} ; Q_{n e c}$ - productivity on condensed pulp within sedimentation area, $\mathrm{m}^{3} / \mathrm{sec} ; b_{o}, h_{o}$ - flow width and height in the initial section of separation area, $\mathrm{m} ; B_{p}, H_{p}$ - flow width and height in the final section of separation area and the initial section of sedimentation area, $\mathrm{m} ; b_{u}, h_{u}$ - flow width and height in the final section of flowing area, $\mathrm{m} ; \alpha_{p}, \beta_{p}$-angles of flow expansion 
along $\mathrm{O}-\mathrm{Z}$ and $\mathrm{O}-\mathrm{Y}$ axes within separation area; $\alpha_{u}, \beta_{u}$ - angles of flow narrowing along $\mathrm{O}-\mathrm{Z}$ and $\mathrm{O}-\mathrm{Y}$ axes within flowing area.

\section{Work purpose}

Development of a method to calculate design parameters of horizontal classifier, based on solid particles motion trajectories analysis within typical segments of flowing area.

\section{Material presentation}

When a solid particle moves in carrying flow, it displaces about liquid, so $U u=u-v$, as a result, liquid itself takes additional movement. [L. Prandtl, 1949], [Kizelvater B.V., 1979] named the force, appeared during accelerated motion of a body about liquid, hydrodynamic long-range action. Let's assume, that flow moves round a particle, in order to identify the mode of a solid particle intercation with carrying media flow at speeds being typical for horizontal classifier (fig. 1). In this case values of Reynolds number $\left(\operatorname{Re}=\frac{u d}{v}\right)$ doesn't exceed 30. It was set earlier, that irregularity of bodies motion about liquid doesn't lead to their rotation or oscillation in the given range, so they move without certain orientation [Kizelvater B.V., 1979]. Also it is known, that the mode is described by single curve if $\operatorname{Re}<30$ for bodies of different shapes, except disks [Kizelvater B.V., 1979]. Indeed, solid particles moves by flow with low relative speed values $v$. Assume, that mode of flow around a particle is laminar within $0,15 \ldots .5 \mathrm{~mm}$ size range. Motion of solid particle relative liquid for little Reynolds numbers $(\operatorname{Re}<1)$, i.e. laminar mode, may be described by known G. Stokes equation [Kizelvater B.V., 1979] $v_{2}=\frac{g\left(\rho_{m}-\rho_{l}\right) d^{2}}{18 \mu}$, where $\rho_{\mathrm{T}}-$ density of solid particle, $к г / \mathrm{M}^{3} ; \rho_{l}$ - liquid density, $к г / \mathrm{M}^{3} ; \mu$-dymanical viscosity, $\mathrm{kg} / \mathrm{m} \cdot \mathrm{sec}$.

Given equation is appropriate when a solid particle falls in motionless liquid after end of initial unsteady motion mode featuring by particle falling with acceleration, i.e. after final speed has been achieved. It is obvious, that particle motion in horizontal carrying flow refers to area of unsteady movement, when acceleration of carrying flow influences sufficiently speed of a solid particle motion. We designate $\lambda=\frac{\rho_{\mathrm{T}} d^{2}}{18 \mu}$ and obtaine expression for relative speed of a solid particle and accelerated liquid flow as the following equations system 


$$
\begin{aligned}
& v_{x}=\lambda\left(\frac{d u_{x}}{d t}\right) \\
& v_{y}=\lambda\left(\frac{d u_{y}}{d t}\right) \\
& v_{z}=\lambda\left(\frac{d u_{z}}{d t}\right)
\end{aligned}
$$

We will obtaine expression for determination of solid particle absolute speed knowing the flow speed value. Particle movement downwards accompanies by additional influence of gravitationla forces, being taken into consideration by free fall speed $v_{2}$. So, absolute speed of particle equals

$$
\begin{aligned}
& U u_{x}=u_{x}-\lambda\left(\frac{d u_{x}}{d t}\right) ; \\
& U u_{y}=u_{y}-\lambda\left(\frac{d u_{y}}{d t}\right) ; \\
& U u_{z}=u_{z}-\lambda\left(\frac{d u_{z}}{d t}\right)+v_{2} .
\end{aligned}
$$

It is obvious, that equations system (1) may be wriitten in the following interpretation, having known experimental free fall speed values $\omega$ of a solid particle in motionless water:

$$
\begin{aligned}
& U u_{x}=u_{x}-\lambda\left(\frac{d u_{x}}{d t}\right) ; \\
& U u_{y}=u_{y}-\lambda\left(\frac{d u_{y}}{d t}\right) ; \\
& U u_{z}=u_{z}-\lambda\left(\frac{d u_{z}}{d t}\right)+\omega .
\end{aligned}
$$

We will use obtained earlier dependences for flow speed and acceleration as components for equations $u$ and $\frac{d u}{d t}$ [7]. We will obtain the trajectory of elementary liquid volume or solid particle motion by determination of a current particle coordinate value. It is necessary to note, that in this case determination of current particle coordinates is interesting only in $\mathrm{X}-\mathrm{Z}$ plane. For this purpose, let's take into consideration the process of elementary liquid volume movement within flow. According to Lagrange method, current coordinate of a particle is a function of initial coordinate and time [6]. Trajectory of liquid volume motion during flat motion is described by system of equations $x=f_{1}\left(x_{0}, z_{0}, t\right) ; z=f_{2}\left(x_{0}, z_{0}, t\right)$. 
Known method takes into consideration liquid volume motion per time unit $d t$ with speed $U_{x}=\frac{d x}{d t} ; U_{z}=\frac{d z}{d t}$. Projection of current coordinate of liquid volume on $\mathrm{X}, \mathrm{Z}$ axes is described by system of the following equations: $d x=U_{x} d t ; d z=U_{z} d t$. Solving given system in a plane, we will obtain $\frac{d x}{U_{x}}=\frac{d z}{U_{z}}$.

Knowing that coordinate $\boldsymbol{z}$ shows depth of particle sedimentation, and $\boldsymbol{x}$ gives the projection of way length on $\mathrm{O}-\mathrm{X}$ axis, current increment of particle sedinemtation depth may be determined according to the expression

$$
d z=\frac{U_{z}}{U_{x}} d x
$$

Increment of particle sedimentation depth is calculated by substitution of known expressions for determination of solid particle absolute speed (2), then

$$
d z=\frac{u_{z}-\lambda\left(\frac{d u_{z}}{d t}\right)+\omega}{u_{x}-\lambda\left(\frac{d u_{x}}{d t}\right)} d x
$$

Knowing, that in accordance with research given in [7], flow speed for sedimentation area is $u_{z p}=\operatorname{tg} \alpha_{p} u_{x p}$, and flow acceleration is equal $\frac{d u_{z}}{d t}=\operatorname{tg} \alpha_{p} \frac{d u_{x}}{d t}$. After substitution, we will obtain expression (3) in such a form:

$$
d z_{p}=\frac{\operatorname{tg} \alpha_{p} u_{x}-\operatorname{tg} \alpha_{p} \lambda\left(\frac{d u_{x}}{d t}\right)+\omega}{u_{x}-\lambda\left(\frac{d u_{x}}{d t}\right)} d x_{p} .
$$

From here, current increment of particle sedimantation depth within separation area will be equal

$$
d z_{p}=\frac{\operatorname{tg} \alpha_{p} U u_{x p}+\omega}{U u_{x p}} d x_{p}
$$

Speed of condensed pulp motion within all section of sedimentation area has constant value $u_{z o}=\frac{q}{B_{p}}$ [7], then increment of solid particle sedimentation depth within sedimentation area is obtained from expression 


$$
d z_{o}=\frac{\frac{q}{B_{p}}+\omega}{U u_{x o}} d x_{o} .
$$

We will obtaine expression

$$
d z_{u}=\frac{\operatorname{tg} \alpha_{u} U u_{x u}+\omega}{U u_{x u}} d x_{u}
$$

for description of solid praticles sedimentation, using recommendations of [7], same to separation area.

Trajectories of solid particles motion may be calculated using expressions for determination of increments of solid particles sedimentation depth values within areas of separation and sedimentation, see example at fig. 2.

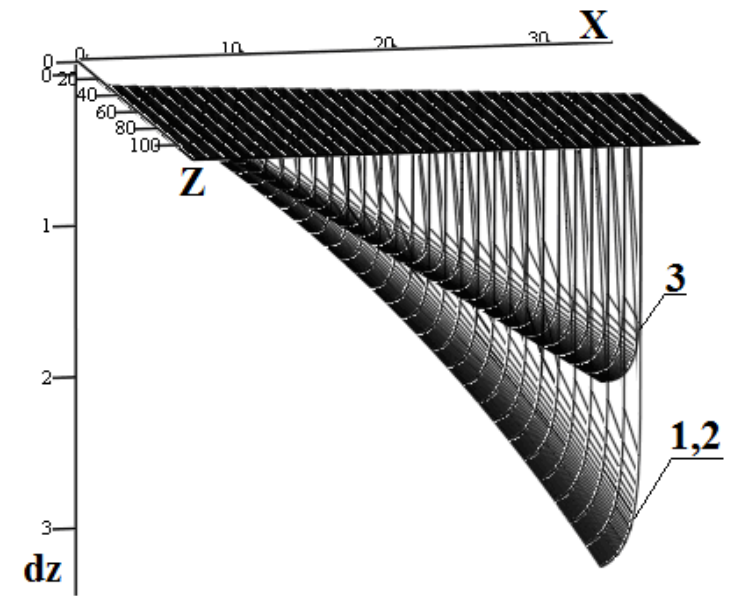

a

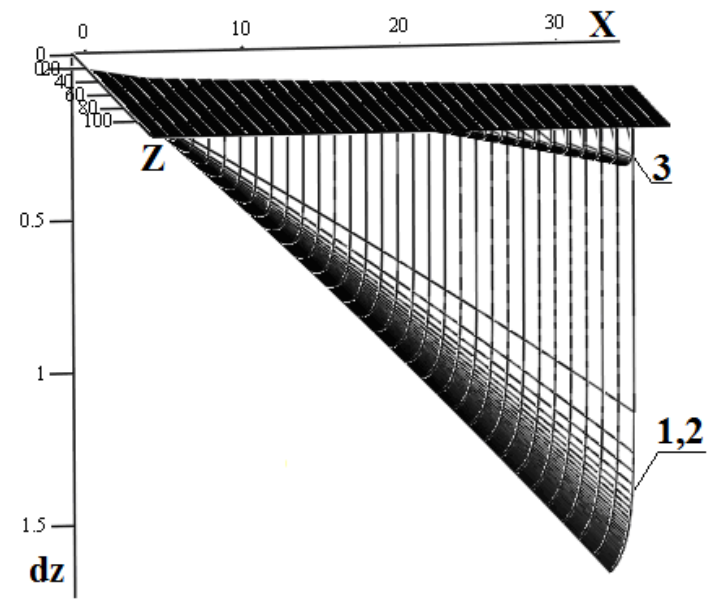

b

1 - solid particles considering motion relatively liquid flow;

2 - solid particles without considering motion relatively liquid flow;

3 - liquid flow.

Figure 2 - Particles motion trajectories within areas of: $\mathrm{a}$ - separation; $\mathrm{b}$ - sedimentation

Trajectory is plotted only for separation and sedimentation areas, because here the process of granular materials classification occurs. Weighed fine solid particles are taken out classification process in flowing area, their trajectories plotting is out of interest in this article.

As we can see at the figure, liquid and solid particles moves along different trajectories already within separation area, solid particles being influenced by gravity forces, considered integral in known experimental parameter - hydraulic size $\omega$. Solid particles moves along curvilinear trajectories, besides difference in their motion description is little due to low values of solid particles movement in liquid flow $v$, together and without taking into consideration movement relatively liquid flow. Sedimentation area features more linear trajectory of solid particles motion. It is 
typical, that difference in movenemt trajectories of liquid flow and solid particles increases.

\section{Conclusions}

It is rational to determine design parameters of horizontal classifier by analysis of solid particles movement trajectories within typical segments of flowing part, obtained by determination of current increment of solid particle sedimentation depth.

\section{REFERENCES}

1. Bondarenko, A.A. (2007), «Substantiation of method for quartz sand dressing during hydromechanized extraction», Mineral dressing: Sci.techn. coll, Iss.29(70)-30(71), pp.70-84.

2. Bondarenko, A.A. (2008), «For substantiation of rational technology of fine materials dressing», Mineral dressing: Sci.-techn. coll., Iss.33(74), pp. 9-15.

2. Bondarenko, A.A. (2008), «Development of construction sand deposits in waterless areas», Mineral dressing: Sci.-techn. coll,. Iss.34(75), pp.25-30.

4. Bondarenko A.A. (2013), «Mathematical modelling of particles movement under high-speed pressure», Metallurgical and mining industry, no.1, pp.66-68.

5. Bondarenko A.A. (2013), «Physical fundamentals of granular materials gravitational separation in horizontal pulp flow», Mineral dressing: Sci.-techn. coll, Iss.52(93), pp.77-80.

6. Bondarenko, A.A. (2013), «Substantiation of horizontal classifier parameters by studying of solid particle interaction with liquid flow», Collection of scientific works of Dneprodzerzhinsk State Technical University. Technical sciences, no.3(23), pp. 114-119.

7. Franchuk, V.P. and A.A.Bondarenko A.A. (2014), «Theoretical fundamentals of liquid flow process in horizontal hydraulic classifier», Geothechnical mechanics, no114, pp.185-191.

\section{СПИСОК ЛИТЕРАТУРЫ}

1. Бондаренко, А.А. Обоснование способа обогащения кварцевых песков при их гидромеханизированной добыче / А.А. Бондаренко // Збагачення корисних копалин: наук.-техн. зб. 2007.- Вип.29 (70)-30(71).- С.70-84

2. Бондаренко, А.А. К обоснованию рациональной технологии обогащения мелкозернистых материалов / А.А. Бондаренко // Збагачення корисних копалин: наук.-техн. зб.-2008.-Вип.33(74).-С.915.

3. Бондаренко, А.А. Освоение месторождений строительных песков в маловодных районах / А.А. Бондаренко // Збагачення корисних копалин: наук.-техн. зб.- 2008.- Вип.34(75).- С.25-30.

4. Бондаренко, А.А. Математическое моделирование движения частиц под влиянием скоростного напора /А.А. Бондаренко // Металлургическая и горнорудная промышленность.- 2013.- №1.- С.66-68.

5. Бондаренко, А.А. Физические основы процесса гравитационного разделения зернистых материалов в горизонтальном потоке пульпы / А.А. Бондаренко // Збагачення корисних копалин: наук.-техн. зб.- 2013.- Вип.52(93).- С.77-80.

6. Бондаренко, А.А. Обоснование параметров горизонтального классификатора путем изучения взаимодействия твердой частицы с потоком жидкости / А.А. Бондаренко // Сборник научных трудов Днепродзержинского государственного технического университета. Технические науки. - 2013. №3(23). $-114-119$.

7. Франчук, В.П. Теоретические основы процесса движения жидкости в гидравлическом горизонтальном классификаторе / В.П. Франчук, А.А. Бондаренко // Геотехнічна механіка: міжвід. зб. наук. праць / ІГТМ НАН України. - Дніпропетровськ, 2014. - № 115. - С. 188 - 199.

\section{About the authors}

Franchuk Vsevolod Petrovich, Doctor of Technical Sciences (D.Sc.), Professor, Professor of Department of Mining Machines and Engineering, State Higher Educational Institution «National mining university» (SHEI «NMU»), Dnepr, Ukraine.

Bondarenko Andrey Alekseyevich, Doctor of Technical Sciences (D.Sc.), Professor, Professor of Department of Mining Machines and Engineering, State Higher Educational Institution «National mining university» (SHEI «NMU»), Dnepr, Ukraine, bondarenkoa@nmu.org.ua. 
Titov Aleksandr Aleksandrovich, Candidate of Technical Sciences (Ph.D.), Associate Professor of Department of Mining Machines and Engineering, State Higher Educational Institution «National mining university» (SHEI «NMU»), Dnepr, Ukraine.

\section{Об авторах}

Франчук Всеволод Петрович, доктор технических наук, профессор, профессор кафедры горных машин и инжиниринга, Государственное высшее учебное заведение «Национальный горный университет» (ГВУЗ «НГУ»), г. Днепр, Украина.

Бондаренко Андрей Алексеевич, доктор технических наук, профессор, профессор кафедры горных машин и инжиниринга, Государственное высшее учебное заведение «Национальный горный университет» (ГВУЗ «НГУ»), г. Днепр, Украина, bondarenkoa@nmu.org.ua.

Титов Александр Александрович, кандидат технических наук, доцент кафедры горных машин и инжиниринга, Государственное высшее учебное заведение «Национальный горный университет» (ГВУЗ «НГУ»), г. Днепр, Украина.

Аннотация. Процесс гравитационной переработки зернистых материалов в горизонтальном потоке пульпы сопровождается течением несущего потока в пределах разнонаклонных поверхностей, а также оттоком вниз сгущенной пульпы. В работе обоснован метод расчета конструктивных параметров горизонтального классификатора, который основан на построении траектории движения твердых частиц.

Для этого рассмотрен процесс перемещения элементарной частицы жидкости в составе потока. Построение траектории движения элементарной частицы жидкости или твердой частицы выполнено путем определения текущей координаты частицы в соответствии с методом Лагранжа. Пользуясь выражениями для определения значений приращения глубины осаждения выполнено построение траектории движения твердых частиц в характерных участках горизонтального классификатора.

Ключевые слова: гравитационное разделение, классификатор горизонтальный, траектория движения.

Анотація. Процес гравітаційної переробки зернистих матеріалів у горизонтальному потоці пульпи супроводжується рухом несучого потоку в межах різнопохилих поверхонь, а також відтоком донизу згущеної пульпи. У роботі обгрунтований метод розрахунку конструктивних параметрів горизонтального класифікатора, заснований на побудові траєкторії руху твердих частинок.

Для цього розглянутий процес переміщення елементарної частинки рідини і складі потоку. Побудову траєкторії руху елементарної частинки рідини або твердої частинки виконано шляхом визначення координати частинки у відповідності до методу Лагранжа. Користуючись виразами для отримання значень прирощення глибини осадження виконана побудова траєкторії руху твердих частинок у характерних ділянках горизонтального класифікатора.

Ключові слова: гравітаційне розділення, класифікатор горизонтальний, траєкторія руху.

Статья поступила в редакцию 23.05. 2017

Рекомендовано к печати д-ром техн. наук Блюссом Б.А. 